This kind of support had a habit of disappearing at times of austerity.

\section{Jenner Museum}

Hope of saving Jenner's house at Cheltenham now seems to be fading. When it became clear, earlier this year, that the building of a new road through the centre of the town would entail the demolition of the house, Jenner's family, local people and the Society of Apothecaries banded together to keep the bulldozers away. The council was persuaded to postpone demolition for six months, largely by the energy of the North American Jenner House Preservation Society, which has its roots in Cheltenham. The Society of Apothecaries asked its members for support, and opened a fund for that purpose. But now it seems that there is more to be done than to prevent the road from being built. The house itself is in a bad condition, partly through natural decay and partly because of vandalism. Saving the house may be easy compared with the job of putting it in order and keeping it that way.

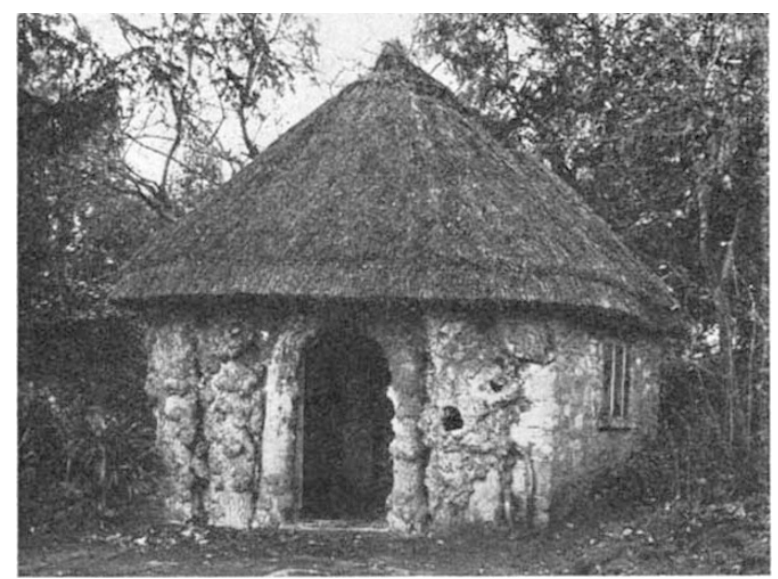

Jenner's hut in the grounds of Berkeley Vicarage where he carried out his first vaccination.

This is why the Faculty of the History of Medicine and Pharmacy at the Society of Apothecaries has decided to transfer its energy to an alternative project for creating a Jenner Museum at Berkeley, Gloucestershire, where Jenner carried out his first vaccination on May 14, 1769. The intention is to use the hut in the grounds of Berkeley Vicarage from which Jenner carried out his first experiments as the base for a permanent museum. What with the new bridge across the Severn, which is nearby, and the ambitious plans for new motorways in the neighbourhood, it may not be at all unreasonable to build a museum in the country rather than in Cheltenham, fifteen miles to the north.

\section{Parliament in Britain}

Asking a question in the House of Lords on November 10 about the Food and Agriculture Organization and world hunger, Lord Brockway said that the plan presented to the Council of Organization in Rome in November covered the decades 1965-85, in which period it was estimated that world population would increase from 3,400 million to 5,000 million. Even if the target of the plan was achieved, scrious malnutrition would remain, and, in three-quarters of the earth, the per capita domestic product would be less than $£ 100$ per year, compared with $£ 1,000$ in the richer countries. Lord Brockway thought that birth control might make some contribution to mitigating the problem and this was strongly pressed by Baroness Summerskill. Lord Brockway himself stressed the major importance of increased production in the developing countries themselves, and of the expansion of trade between developed and developing countries, and between developing countries themselves. Lord Beswick, replying for the Government, pointed out that the annual report, which was also considered in Rome, emphasized that last year food production in the developing countries fell, although it had increased in North America and, to a lesser extent, in Western Europe. The Indicative World Plan, to which Lord Brockway referred, was not yet complete, but it had been fully encouraged by the British Government, and Lord Beswick thought it should facilitate discussions which would assist the fuller utilization of world resources. He also referred to the research carried out by the Ministry of Overseas Development through its Overseas Liaison Unit at the National Institute of Agricultural Engineering at Silsoe, particularly in designing and developing a simple hand operated paddy transplanter which could promote a really significant increase in rice cultivation in many areas. He agreed as to the importance of fisheries research and of resources of the arid regions, and the work of the United Nations Educational, Scientific and Cultural Organization and of the Food and Agriculture Organization in both these fields had the full support of the British Government.

Is a written answer on November 9, the Minister of State at the Department of Education and Science, Mr. G. Roberts, said that Science Research Council grants to Scottish universities, including the Heriot Watt College, totalled $£ 2,630,000$ at September 30 , 1966. In replying to questions in the House of Commons on November 10, the Secretary of State for Education and Science, Mr. A. Crosland, said that the Science Research Council's policy on postgraduate training, with particular reference to closer collaboration between universities and industry, was being revised by a working party under Lord Halsbury, and that he, the minister, was asking all the research councils for their views on the Swann report, some parts of which had already been anticipated by the Science Research Council. He also hoped that, with the help of the Council for Scientific Policy, it might soon be possible to reach decisions on allocations of research grants for a three year period. Questioned regarding progress in implementing the recommendations of the Flowers Committee, Mr. Crosland said that the Computer Board had now been established under the chairmanship of Prof. Flowers. The universities with $K D F 9$ computers had ordered up-graded machines, some of which had been installed and were working. The allocation of $£ 3$ million for $1966-67$ was almost entirely committed, as well as $£ 2$ million of the allocation for 1967-68. The Computer Board was discussing with the universities the programme for the years ahead, the principles which should govern the proposed regional centres, and the provision of adequate soft. ware for the computers now being installed in universities. 